\title{
Using ISSR markers in determination of genetic relationship between $2 n=54$ and $2 n=60$ cytotypes of Nannospalax xanthodon (Nordmann, 1840) (Mammalia, Rodentia) from Central Anatolia
}

\author{
Tuba Ya c *, Eda Şen \& Rafig R. Gurbanov
}

ABSTRACT. A total of 36 samples of $2 n=54$ and $2 n=60$ cytotypes of Nannospalax xanthodon, distributed in the Central Anatolia region of Turkey, were analyzed for the first time by using inter-simple sequence repeat-polymerase chain reaction (ISSR-PCR) technique. The analysis revealed 112 ISSR bands, 101 of which were polymorphic. Seven ISSR primers $\left((\mathrm{AG})_{8} \mathrm{~T},(\mathrm{GGAGA})_{5},(\mathrm{GACA})_{4},(\mathrm{TG})_{8} \mathrm{~A},(\mathrm{CAG})_{5}\right.$ $\mathrm{GC},(\mathrm{CAG})_{4} \mathrm{AC}$ and $\left.(\mathrm{GA})_{8} \mathrm{AC}\right)$ ) were optimized from total 20 primers. $(\mathrm{AG})_{8} \mathrm{~T}$ and $(\mathrm{GA})_{8} \mathrm{AC}$ primers were most informative to distinguish cytotypes by producing specific bands for $2 n=54$ and $2 n=60$. The cytotypes in genetically close relationships were separated into three different groups by UPGMA cluster analysis, in which, the highest genetic diversity was measured for $2 n=60$. Our results showed that ISSR markers can be used as a simple and reliable molecular tool, for the estimation of genetic diversity in cytotypes of Nannospalax at low range genetic distances.

How to cite this article: Ya c T., Şen E., Gurbanov R.R. 2018. Using ISSR markers in determination of genetic relationship between $2 n=54$ and $2 n=60$ cytotypes of Nannospalax xanthodon (Nordmann, 1840) (Mammalia, Rodentia) from Central Anatolia// Russian J. Theriol. Vol.17. No.2. P.100-107. doi: 10.15298/ rusjtheriol.17.2.06

KEY WORDS: cytotype, ISSR, Nannospalax xanthodon, Turkey.

TubaYac [tuba.yagci@bilecik.edu.tr], Department of Molecular Biology and Genetics, Faculty of Science and Arts and Biotechnology Application and Research Center of Bilecik eyh Edebali University, Bilecik 11230, Turkey; Eda en [edasenmbg@bilecik.edu.tr], Department of Molecular Biology and Genetics, Faculty of Science and Arts, Bilecik Şeyh Edebali University, Bilecik 11230, Turkey; Rafig R. Gurbanov [rafig.gurbanov@bilecik.edu.tr], Department of Molecular Biology and Genetics, Faculty of Science and Arts and Biotechnology Application and Research Center of Bilecik Seyh Edebali University, Bilecik 11230, Turkey.

\section{Использование ISSR маркеров в определении генетической связи между $2 n=54$ и 2n = 60 цитотипами Nannospalax xanthodon (Nordmann, 1840) (Mammalia, Rodentia) из Центральной Анатолии}

\author{
Т. Ягчи*, Е. Шен, Р.Р. Гурбанов
}

РЕЗЮМЕ. 36 образцов $2 n=54$ и $2 n=60$ цитотипов Nannospalax xanthodon из Центральной Анатолии, Турция, были впервые проанализированы с использованием ISSR маркеров. Анализ выявил 112 полос ISSR, 101 из которых были полиморфными. Из двадцати ISSR праймеров были выбраны семь: ((AG) $)_{8}$, $(\mathrm{GGAGA})_{5},(\mathrm{GACA})_{4},(\mathrm{TG})_{8} \mathrm{~A},(\mathrm{CAG})_{5} \mathrm{GC},(\mathrm{CAG})_{4} \mathrm{AC}$ and $\left.\left.(\mathrm{GA})_{8} \mathrm{AC}\right)\right)_{\text {. }}$ Праймеры $(\mathrm{AG})_{8} \mathrm{~T}$ и $(\mathrm{GA})_{8} \mathrm{AC}$ создавали специфические полосы для $2 n=54$ и $2 n=60$ и были наиболее информативными для различения цитотипов. По результатам кластерного анализа (UPGMA) генетически близкие цитотипы образуют 3 группы, наиболее высокое разнообразие отмечено для цитотипа $2 n=60$. Наши результаты показали, что маркеры ISSR можно использовать в качестве простого и надежного молекулярного инструмента для оценки генетического разнообразия в цитотипах Nannospalax при низких генетических дистанциях.

КЛЮЧЕВЫЕ СЛОВА: цитотип, ISSR, Nannospalax xanthodon, Турция. 


\section{Introduction}

The Spalacidae family is distributed in Northeast Africa, the Balkans, Southeast Europe, Central Asia, the Middle East, and the Caucasus (Topachevskii, 1969; Savic \& Nevo, 1990). Previously, Gromov \& Baranova (1981) recognized two genera of this family: Nannospalax Palmer, 1903 and Spalax Guldenstaedt, 1770. The Nannospalax differ from Spalax because their karyotypes include mainly acrocentric autosomes (Arslan \& Bölükbaş, 2010; Arslan et al., 2010; Matur et al., 2011; Sözen et al., 2011). Therefore the generic name Nannospalax is used in this study.

In Turkey, the genus Nannospalax is commonly represented by three species - Nannospalax leucodon (Nordmann, 1840), N. xanthodon (Nordmann, 1840), and $N$. ehrenbergi (Nehring, 1898). The number of diploid chromosomes $(2 n)$ of $N$. xanthodon ranges from 36 to 60 and the fundamental number (NF) ranges from 66 to 92 (Sözen et al., 2013; Kank 1 ç et al., 2015). Cytological studies revealed over 50 cytotypes (individuals with different chromosomal numbers within the species) for Turkish mole rats, and this extraordinary karyological diversity is an important taxonomic problem (Yigit et al., 2006; Kryštufek \& Vohralík, 2009; Arslan \& Zima, 2014; Sözen et al., 2015; Kank 1 ç et al., 2017). The taxonomic status and the geographical borders of species and cytotypes of the genus Nannospalax is still a matter of debate. Researchers have been seeking answers to the question of how taxonomically evaluate cytotypes using molecular techniques whether they are different species or not.

The first genetic research conducted on the genus Nannospalax was allozyme electrophoresis study by Nevo et al. (1995). In this study, it was determined that different chromosomal forms have distinct alleles in most of the studied enzyme systems. Moreover, Suzuki et al. (1996) investigated the differences in ribosomal DNA (rDNA) and mitochondrial DNA (mtDNA) between $N$. xanthodon and $N$. ehrenbergi species by using restriction fragment length polymorphism (RFLP) technique. In terms of genetic polymorphism, they reported discrimination between these two species at a high rate.

Recent molecular studies have provided remarkable data in the understanding of Turkish mole rat phylogeny. Although the studies based on mtDNA did not show differences in the Anatolian cytotypes at the species level, significant separations were reported between several cytotypes (Arslan et al., 2010; Kandemir et al., 2012; Kank 1 ç et al., 2013, 2015; Kank 1 ç \& Güp nar, 2014). In addition, Hadid et al. (2012) identified four clades (leucodon, xanthodon, ehrenbergi, vasvarii) for the Anatolian mole rats by phylogenetic analysis of five mtDNA sequences. Moreover, Kank 1 ç et al. (2013) indicated that random amplification of polymorphic DNA (RAPD) bands could be distinguishing molecular markers among chromosomal races, by using RAPD technique.
Almost all the above-mentioned studies suggest the need for more localities and more molecular data in order to resolve the taxonomic complexity of Nannospalax. In this framework, we aimed to determine the genetic characterization between $2 n=54$ and $2 n=60$ cytotypes of $N$. xanthodon distributed in the Central Anatolia region by using distinguishing markers and also to show the applicability of ISSR-PCR technique for the discrimination of these cytotypes. This molecular technique allows simple and reliable primer design without a need for sequence information for the determination of evolutionary relationships between various species (Zietkiewicz et al., 1994; Joshi et al., 2000; Bugarski-Stanojević et al., 2008, 2011).

\section{Materials and methods}

\section{Animal materials and locations}

This study consisted of $36 \mathrm{~N}$. xanthodon specimens from 8 different localities in Central Anatolia region (Fig. 1). Liver tissues were preserved at $-80^{\circ} \mathrm{C}$ at the Department of Molecular Biology and Genetics, Bilecik eyh Edebali University, Bilecik, Turkey. Karyological data were obtained from the previous study (Yagci, 2010).

\section{DNA extraction and ISSR-PCR amplifica-} tion

DNA was isolated from liver tissues of 36 individuals of $N$. xanthodon by using DNA extraction kit (GeneJET Genomic DNA Purification Kit, Thermo Scientific, USA). DNA purity was determined by NanoDrop and the degree of DNA degradation was measured using $0.1 \%$ agarose gels with $0.5 \mu \mathrm{g} / \mathrm{ml}$ ethidium bromide. ISSR-PCR amplification was performed from the obtained genomic DNA. 18 primers (UBC807, 809, $811,813,818,826,827,828,830,841,842,843,864$, $866,868,873,876$, and 880 ) were randomly chosen from UBC (British Columbia University) primer set \#9 and tested in ISSR-PCR analysis. In addition, primers $52(\mathrm{CAG})_{5} \mathrm{GC} 32$ and $52(\mathrm{CAG})_{4}$ AC 32 were custom designed (Sentegen) and tested, since they were previously found as appropriate primers for rodent species (Bugarski-Stanojević et al., 2011). Only 7 primers (UBC807, 811, 828, 873, 880, (CAG) $)_{5}$ GC and (CAG) ${ }_{4}$ $\mathrm{AC}$ producing clear and reproducible bands were chosen for ISSR analysis (Tab. 1). PCR amplifications were performed for a total volume of $25 \mathrm{uL}$ in the BioRad T100 ${ }^{\mathrm{TM}}$ Thermal cycler by using 0.3 ul Taq DNA polymerase enzyme (5u/ul, Thermo Scientific, USA), 2.5 ul 10x PCR Buffer, 1.5uL $\mathrm{MgCl}_{2}(25 \mathrm{mM}), 0.4 \mathrm{uL}$ dNTP $(10 \mathrm{mM}), 1 \mathrm{u} 1$ DNA $(30 \mathrm{ng}), 1 \mathrm{ul}$ primer and 16.8 ul dd $\mathrm{H}_{2} \mathrm{O}$. The PCR program started with an initial phase of $5 \mathrm{~min}$ at $94^{\circ} \mathrm{C}$, followed by 40 cycles of $45 \mathrm{~s}$ at $94{ }^{\circ} \mathrm{C}, 45 \mathrm{~s}$ at $40^{\circ} \mathrm{C}, 2 \mathrm{~min}$ at $72^{\circ} \mathrm{C}$ and $10 \mathrm{~min}$ final elongation at $72{ }^{\circ} \mathrm{C}$. ISSR amplification products were stained with ethidium bromide and eluted at $90 \mathrm{~V}$ with $1 \mathrm{X}$ TBE buffer on $1 \%$ agarose gel electrophoresis. 


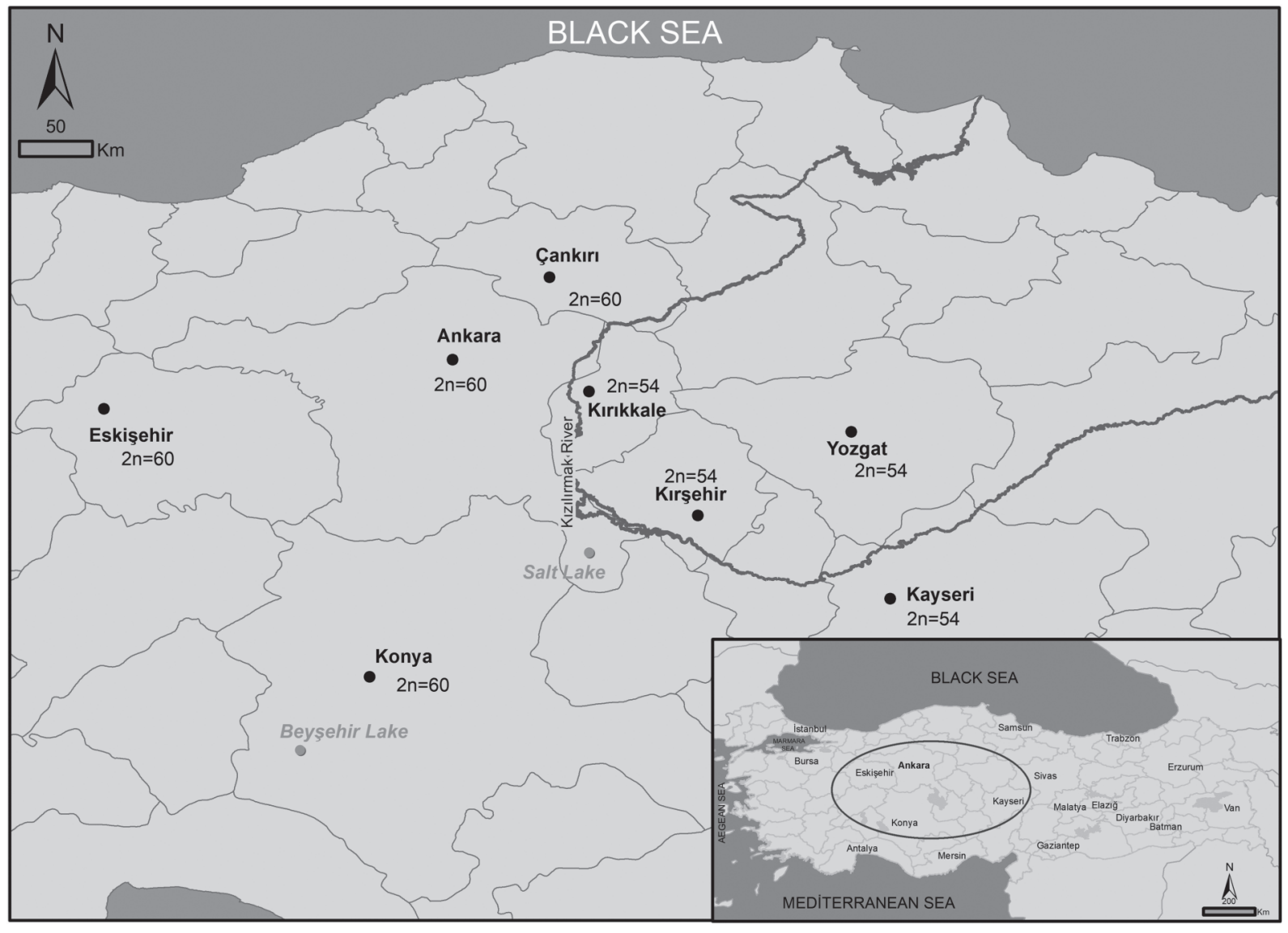

Fig. 1. Localities and sample sizes of ISSR analysed $N$. xanthodon individuals. $2 n-$ diploid chromosome number, $n-$ specimens number.

Table 1. List of ISSR primers used to detect polymorphism.

\begin{tabular}{|l|c|c|c|}
\hline Primer Sequence & Number of bands & Number of polymorphic bands & Polymorphism, $\%$ \\
\hline UBC $807(\mathrm{AG})_{8} \mathrm{~T}$ & 20 & 20 & 100 \\
\hline UBC $811(\mathrm{GA})_{8} \mathrm{AC}$ & 14 & 14 & 100 \\
\hline UBC $828(\mathrm{TC})_{8} \mathrm{~A}$ & 9 & 7 & 78 \\
\hline UBC $873(\mathrm{GACA})_{4}$ & 14 & 12 & 86 \\
\hline UBC $880(\mathrm{GGAGA})_{5}$ & 17 & 15 & 88 \\
\hline Custom primer $(\mathrm{CAG})_{5} \mathrm{GC}$ & 19 & 16 & 84 \\
\hline Custom primer $(\mathrm{CAG})_{4} \mathrm{AC}$ & 19 & 17 & 89 \\
\hline ISSR total & 112 & 101 & 90 \\
\hline
\end{tabular}

Molecular sizes of amplified products were estimated using 100-10000 bp DNA ladder marker (GeneRuler DNA Ladder Mix, Thermo Scientific, USA).

\section{Data analysis}

DNA band profiles were scored based on the DNA ladder from gel photographs. Scoring was done by recording in the presence of a band (1) and in the absence of band (0). The genetic distance matrix created in the presence and absence of bands is calculated according to Nei (1978). To calculate genetic diversity, Multivariate Statistical Package (MVSP) v. 3.22 and
POPGENE v. 1.32 (Population Genetic Analysis) were used (Yeh et al., 1999). This was done by the UPGMA analysis, which was calculated based on the dendrogram derived from the Jaccard coefficient (Fig. 2).

\section{Results}

In this study, 7 ISSR primers which gave the best amplification from total 20 primers were selected for the analysis of $N$. xanthodon cytotypes. These 7 primers amplified a total of 101 polymorphic loci, of estimated sizes from 150 to $2200 \mathrm{bp}$. The numbers of 


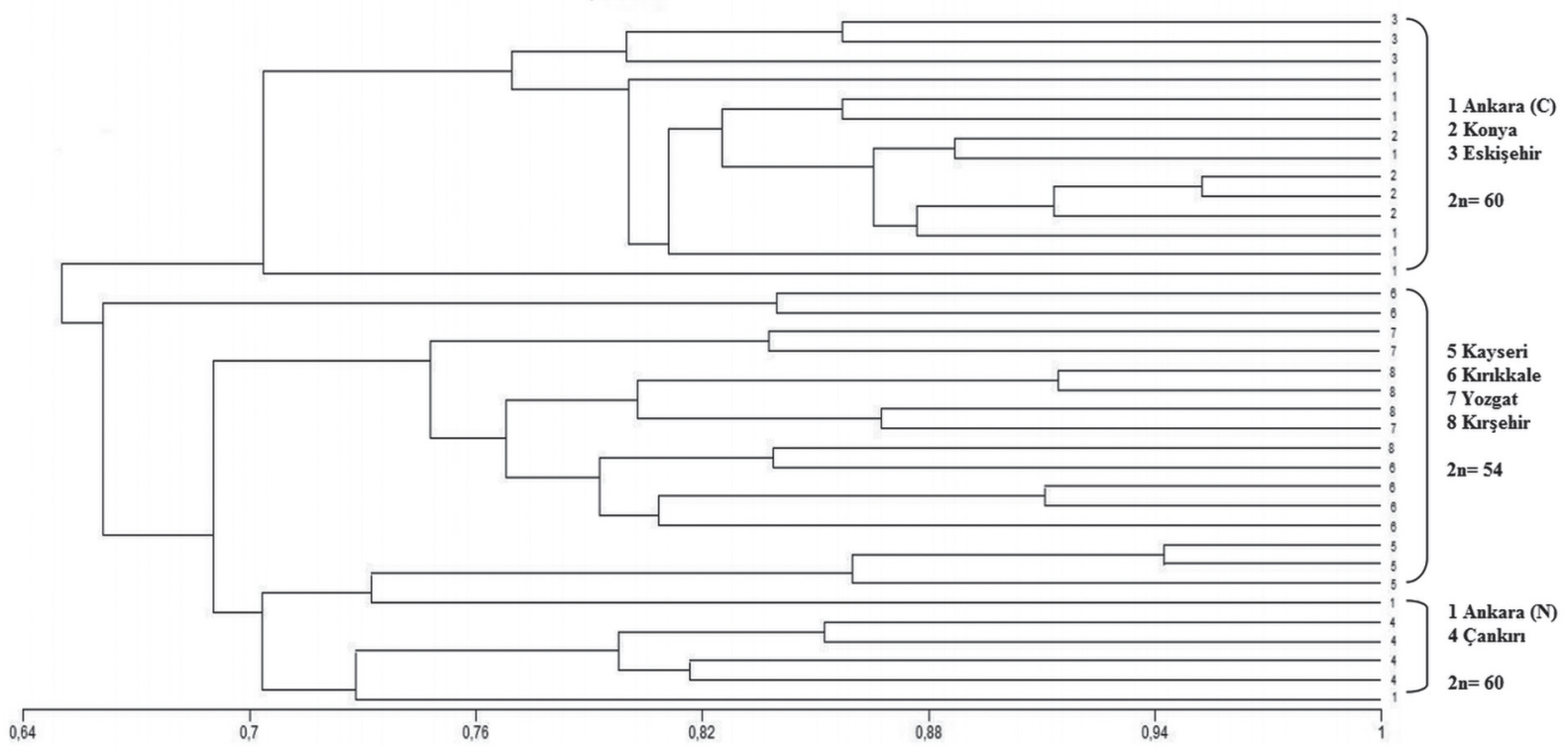

Fig. 2. Dendrogram of genetic similarity among 36 N. xanthodon specimens obtained from ISSR markers using the UPGMA method.

polymorphic bands were between 7 and 20. The average number of polymorphic bands per primer was calculated as 14.42 (Tab. 1). The polymorphism rates of the primers range from $78 \%$ to $100 \%$ (Fig. 3). Total polymorphism rate was recorded as $90 \%$. According to these data, primers (AG) $)_{8} \mathrm{~T}$ and $(\mathrm{GA})_{8} \mathrm{AC}$ are excellent primers for discriminating cytotypes $(100 \%)$, since they produced high and specific bands. Nei's original genetic distances were calculated independently for the specimens separated on the basis of all 8 localities and $N$. xanthodon cytotypes $(2 n=54,60)$. In the $2 n=54$ and $2 n=60$ cytotypes, the average similarity was calculated as $89 \%$ using 7 ISSR markers and this high similarity is because of their common ancestry (Tabs 2, 3). When locality samples were evaluated, the highest similarity was $91 \%$ in Ankara and Konya populations, because Ankara and Konya's populations share the same number of diploid chromosomes $(2 n=60)$. The highest average distance (35\%) was seen in Konya and Yozgat populations since these geographic patterns are separated by diploid chromosome numbers $(2 n=60,2 n=$ 54, respectively).

Table 2. Nei's original measures average of genetic identity and genetic distance between $N$. xanthodon cytotypes

$(2 n=54$ and $2 n=60)$.

\begin{tabular}{|c|c|c|}
\hline Cytotypes & $2 n=60$ & $2 n=54$ \\
\hline $2 n=60$ & $* * * *$ & 0.8984 \\
\hline $2 n=54$ & 0.1071 & $* * * *$ \\
\hline
\end{tabular}

The genetic polymorphism between populations and cytotypes of $N$. xanthodon was calculated to present possible differences in between a total of $36 \mathrm{~N}$. xanthodon individuals in 8 provinces of Central Anatolia and between two cytotypes. The highest genetic diversity index as locality was found in Ankara populations $(\mathrm{h}=0.216$ and $\mathrm{I}=0328)$, whereas Konya populations have the lowest genetic diversity $(\mathrm{h}=0.059, \mathrm{I}=0.089)$. When the samples separated by cytotypes are taken into account, the percentage of polymorphic loci in $2 n=60$ is found higher than $2 n=54$ (Tabs 4,5$)$.

The genetic distance matrix was calculated using the polymorphism ratios determined by the markers indicated in Table 1. In the UPGMA analysis, which was calculated based on the Jaccard coefficient; two main groups were revealed significantly. Group I, consisted of samples with diploid chromosome numbers $2 n=60$ and the samples from the localities with boundaries between each other (Eskişehir, Ankara, Konya). Group II was separated from Group I with regard to all of the $2 n=54$ species ( $\mathrm{K} \mathrm{r}$ kkale, $\mathrm{K} \mathrm{r}$ ehir, Yozgat, Kayseri) inside the K z 1 mak basin. These two groups were separated from each other both chromosomally and geographically by $\mathrm{K}$ z 1 makRiver. A small population of 6 samples isolated from $2 n=54$, which we can refer as Group III, contains $2 n=60$ samples taken from the north of Central Anatolia, Çank r, and north of Ankara (Figs 1-2).

\section{Discussion}

Wahrman et al. (1969) proposed that the appearance of ancestral Spalax could be any place in Southeastern Europe or Anatolia. The oldest spalacid Heramys eviensis living in early Miocene epoch was re- 
A

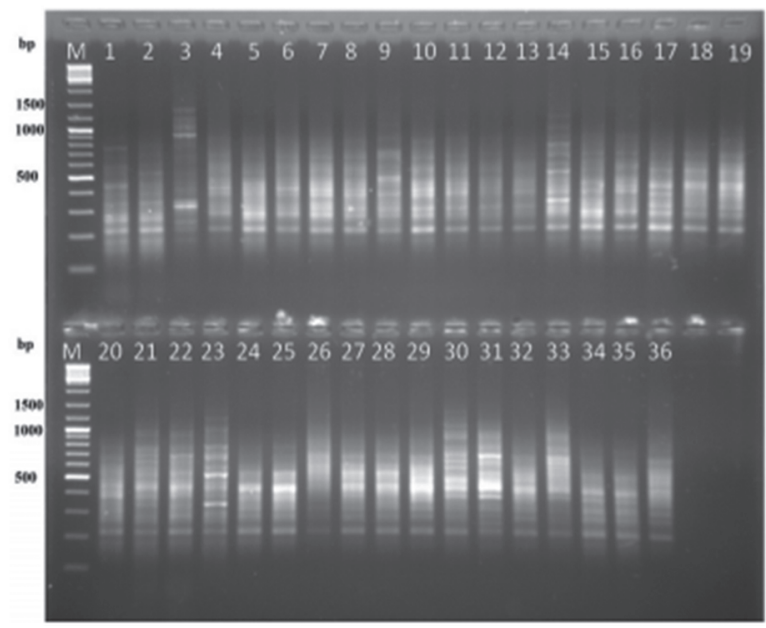

B

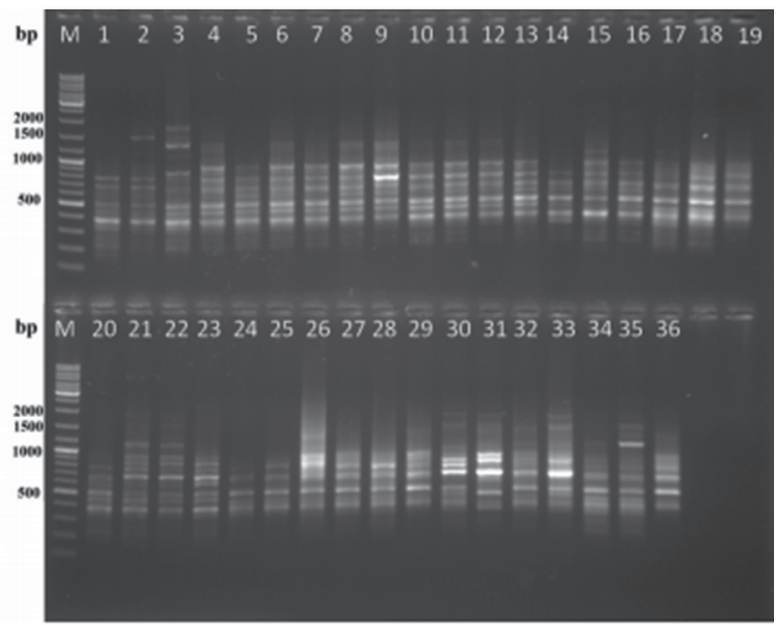

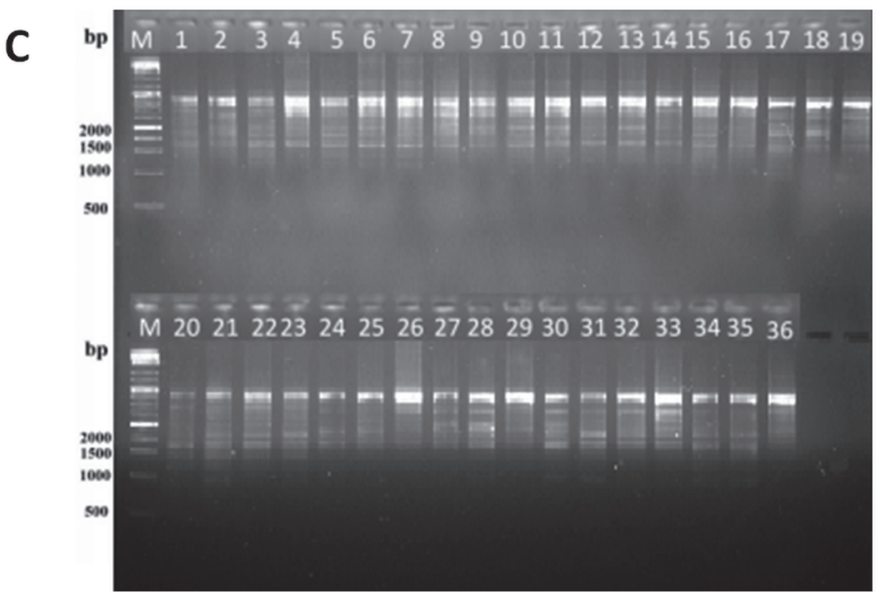

Fig. 3. Gel electrophoresis profiles of PCR products by using ISSR primers for total 36 N. xanthodon specimens. Primers showing the highest polymorphism: A - UBC 807, B - UBC 811. Primers showing the lowest polymorphism: C - UBC 828. M - DNA marker; $2 n=60(1-19), 2 n=54(20-36)$.

Table 3. Nei's original measures average of genetic identity and genetic distance between geographic samples of N. xanthodon.

\begin{tabular}{|c|c|c|c|c|c|c|c|c|}
\hline Samples & 1 & 2 & 3 & 4 & 5 & 6 & 7 & 8 \\
\hline 1 & $* * * *$ & 0.9126 & 0.8750 & 0.8412 & 0.8141 & 0.8422 & 0.7713 & 0.7861 \\
\hline 2 & 0.0914 & $* * * *$ & 0.8711 & 0.7527 & 0.7812 & 0.7672 & 0.6992 & 0.7765 \\
\hline 3 & 0.1335 & 0.1380 & $* * * *$ & 0.7995 & 0.8172 & 0.7798 & 0.7439 & 0.7906 \\
\hline 4 & 0.1729 & 0.2840 & 0.2237 & $* * * *$ & 0.7875 & 0.8242 & 0.7999 & 0.7931 \\
\hline 5 & 0.2057 & 0.2469 & 0.2019 & 0.2388 & $* * * *$ & 0.8225 & 0.8140 & 0.8319 \\
\hline 6 & 0.1717 & 0.2650 & 0.2487 & 0.1934 & 0.1954 & $* * * *$ & 0.8549 & 0.8815 \\
\hline 7 & 0.2597 & 0.3578 & 0.2958 & 0.2232 & 0.2058 & 0.1568 & $* * * *$ & 0.8667 \\
\hline 8 & 0.2407 & 0.2530 & 0.2350 & 0.2319 & 0.1841 & 0.1261 & 0.1430 & $* * * *$ \\
\hline
\end{tabular}

1 - Ankara, 2 - Konya, 3 - Eskişehir, 4 - Çank r , 5-Kayseri, 6 - K r kkale, 7 - Yozgat, 8 - K r ehir. 
Table 4. Genetic diversity according to locality distribution of N. xanthodon.

\begin{tabular}{|c|c|c|c|c|c|c|c|c|}
\hline Localities and coordinates & $2 n$ & $\mathrm{NF}$ & $\mathrm{N}$ & $n_{a}$ & $n_{e}$ & $I$ & $h$ & $P \%$ \\
\hline $\begin{array}{ll}\text { Yenimahalle, Ankara } & 39^{\circ} 57^{\prime} \mathrm{N}, 32^{\circ} 47^{\prime} \mathrm{E} \\
\text { Altındağ, Ankara } & 40^{\circ} 02^{\prime} \mathrm{N}, 32^{\circ} 56^{\prime} \mathrm{E}\end{array}$ & 60 & 82 & 9 & 1.687 & 1.368 & 0.328 & 0.216 & 68.75 \\
\hline $\begin{array}{lc}\text { Kulu, Konya } & 39^{\circ} 11^{\prime} \mathrm{N}, 33^{\circ} 08^{\prime} \mathrm{E} \\
\text { Cihanbeyli, Konya } & 38^{\circ} 40^{\prime} \mathrm{N}, 32^{\circ} 55^{\prime} \mathrm{E}\end{array}$ & 60 & 80 & 4 & 1.160 & 1.102 & 0.089 & 0.059 & 16.07 \\
\hline $\begin{array}{l}\text { Sarıcakaya, Eskissehir } 40^{\circ} 05^{\prime} \mathrm{N}, 30^{\circ} 36^{\prime} \mathrm{E} \\
\text { Mihalgazi, Eskişehir } 40^{\circ} 02^{\prime} \mathrm{N}, 30^{\circ} 36^{\prime} \mathrm{E}\end{array}$ & 60 & 80 & 3 & 1.285 & 1.197 & 0.165 & 0.112 & 28.57 \\
\hline $\begin{array}{ll}\text { Kızılırmak, Çankırı } & 40^{\circ} 24^{\prime} \mathrm{N}, 34^{\circ} 07^{\prime} \mathrm{E} \\
\text { Eldivan, Çankırı } & 40^{\circ} 32^{\prime} \mathrm{N}, 33^{\circ} 29^{\prime} \mathrm{E}\end{array}$ & 60 & 78 & 4 & 1.348 & 1.244 & 0.200 & 0.137 & 34.82 \\
\hline $\begin{array}{ll}\text { Bayramhac1, Kayseri } & 38^{\circ} 49^{\prime} \mathrm{N}, 35^{\circ} 01^{\prime} \mathrm{E} \\
\text { Yuval, Kayseri } & 38^{\circ} 49^{\prime} \mathrm{N}, 35^{\circ} 05^{\prime} \mathrm{E}\end{array}$ & 54 & 74 & 3 & 1.160 & 1.111 & 0.093 & 0.063 & 16.07 \\
\hline $\begin{array}{ll}\text { Çelebi, Kırıkkale } & 39^{\circ} 27^{\prime} \mathrm{N}, 33^{\circ} 31^{\prime} \mathrm{E} \\
\text { Yahşihan, Kırıkkale } & 39^{\circ} 50^{\prime} \mathrm{N}, 33^{\circ} 27^{\prime} \mathrm{E}\end{array}$ & 54 & 74 & 6 & 1.410 & 1.248 & 0.218 & 0.145 & 41.07 \\
\hline $\begin{array}{l}39^{\circ} 40^{\prime} \mathrm{N}, 34^{\circ} 37^{\prime} \mathrm{E} \\
39^{\circ} 29^{\prime} \mathrm{N}, 34^{\circ} 44^{\prime} \mathrm{E}\end{array}$ & 54 & 74 & 3 & 1.258 & 1.190 & 0.154 & 0.106 & 25.89 \\
\hline $\begin{array}{lr}\text { Akpınar, Kırssehir } & 39^{\circ} 38^{\prime} \mathrm{N}, 33^{\circ} 54^{\prime} \mathrm{E} \\
\text { Bayramözü, Kırşehir } & 39^{\circ} 23^{\prime} \mathrm{N}, 33^{\circ} 35^{\prime} \mathrm{E}\end{array}$ & 54 & 74 & 4 & 1.330 & 1.198 & 0.175 & 0.116 & 33.04 \\
\hline
\end{tabular}

$2 n$ - cytotypes, NF - fundamental number, $\mathrm{N}$ - sample size, $n_{a}$ - average allele number per locus, $n_{e}$ - the effective number of alleles, $I$ - Shannon's diversity, $h$ - Nei's gene diversity, $P \%$ - the percentage of polymorphic loci.

Table 5. Genetic diversity of $N$. xanthodon cytotypes $(2 n=60$ and $2 n=54)$.

\begin{tabular}{|c|c|c|c|c|c|c|}
\hline Cytotypes & $\mathrm{N}$ & $n_{a}$ & $n_{e}$ & $I$ & $h$ & $P \%$ \\
\hline $2 n=60$ & 20 & 1.803 & 1.402 & 0.367 & 0.240 & 80.36 \\
\hline $2 n=54$ & 16 & 1.687 & 1.358 & 0.321 & 0.211 & 68.75 \\
\hline
\end{tabular}

$\mathrm{N}$ - sample size, $n_{a}$ — average allele number per locus, $n_{e}$ - the effective number of alleles, $I$ - Shannon's diversity, $h$ - Nei's gene diversity, $P \%$ - the percentage of polymorphic loci.

corded by Klein Hofmeijer \& de Bruijn (1985) in Greece (Nevo, 1991). The latest studies have presented the facts that Anatolian Spalacidae originating from muroid-cricetoid stock have evolved 20-30 million years ago during the Oligocene epoch and distributed across the Northern Africa, Middle East, Russia, and Balkans. Spalacidae species distributed in Europe have an Asian origin. Before the early Pleistocene, blind mole rat populations have crossed the Balkan Peninsula and after the formation of Bosphorus and Dardanelles straits they were separated and speciatiated independently (Yüksel \& Gülkaç, 1990). The original factors affecting the distribution of rodents in Turkey are vegetation structure, climate, and altitude (Yi it et al., 1999).

The idea that the climatic properties are effective in chromosomal distribution of Spalacidae family in Turkey is supported by the distribution of $2 n=38$ in the humid Aegean region and $2 n=60$ in the arid Central
Anatolia region (Nevo et al., 1994, 1995). In this study, 8 populations from the Central Anatolian region with an arid clime have the same climatic characteristics. However, as they consist of two different cytotypes, it seems that the effect of drought is open to different and contradictory interpretations. In this respect, even our findings do not clearly reveal that there is a precise rule for this issue. In the further studies, not only the precipitation characteristics but also the use of the drought with other climatic characteristics (i.e. the geological structure of localities, water holding feature of soil, slope, elevation and etc.) can be evaluated for the localities in the same climate zone.

Ivanitskaya et al. (2008), recorded different populations of $2 n=60$ between Northern Anatolia and Central Anatolia using molecular cytogenetic techniques. Kandemir et al. (2012) identified a different clade of Northern Anatolia and differentiated them from other popu- 
lations by characterizing genetic variations of cytochrome $b$ gene sequences. According to Matur et al. (2011), there is an independent evolutionary pathway for Northern clade identified as ancestral karyotype $2 n=60 \mathrm{R}$. Although, the diploid chromosome numbers $(2 n=60)$ were same in our study, the samples belonging to North were separated as a different group (Group III) and differentiated from Central Anatolian samples. Kank 1 ç \& Gürp nar (2014) emphasized that cytotype $2 n=60$ has the highest number of common alleles in Central Anatolia for $N$. xanthodon and $N$. ehrenbergi based on mtDNA analysis, which was also supported in our study.

According to several studies, a generalization of a "cytotypes - equals - species" opinion is not appropriate, based on low genetic deviations especially in cytotypes of $N$. leucodon (Kryštufek et al., 2012). Another opinion is that several cytotypes of $N$. xanthodon such as $2 n=54$ and $2 n=60$ should be considered as different biological species (Arslan et al., 2010, Kank 1 ç et al., 2013). In our study, $2 n=54,2 n=60 \mathrm{C}$ (Central) and $2 n=60 \mathrm{~N}$ (Northern) cytotypes were separated at a low genetic distance from each other with UPGMA dendrogram, but this differentiation is not enough to consider them as separate species. According to our results, $2 n=$ $60 \mathrm{C}$ and $2 n=60 \mathrm{~N}$ populations might have different origins. Since, $2 n=54$ population is genetically more close to $2 n=60 \mathrm{~N}$ than $2 n=60 \mathrm{C}, 2 n=54$ can be originated from $2 n=60 \mathrm{~N}$. Genetic differences among the cytotypes of Nannospalax genus in Turkey have not yet been clarified. All the authors reported that the collection of further molecular data is necessary to better evaluate the phylogenetic relationship. In addition, they specify the importance of intrapopulation variations in this respect. In short, putting out the phylogenetic and taxonomic results for this species seems to be extremely hard, since they possess remarkable chromosomal diversities even at very close localities in line with morphological similarities. However, the detection of very small distinction and/or similarity between cytotypes and individuals is important for the explanation of the genetic relationship between mole rats during their speciation processes in evolution, which is accepted as a common consensus between scientists. Evaluation of molecular studies together with karyological and morphological studies is recommended to illuminate the taxonomic classification of Spalacidae. Further cytogenetic studies should be performed between cytotypes of Nannospalax by taking into account of Robertsonian translocations, B chromosomes and individual variations causing chromosomal diversity.

ISSR marker systems are widely used DNA markers to predict and characterize the genetic diversities in natural populations. Numerous studies have been used ISSR markers for the determination of relationship degrees in sibling, cryptic, sympatric animals and plant species. In these studies, the reliability of ISSR markers were also confirmed by the use of different marker such as cytochrome $b$ gene analysis of mtDNA, isoenzymes,
ISSR and RAPD PCR (Bugarski-Stanojević et al., 2008; Jojić et al., 2014; Zhigileva et al., 2014; Buczkowska et al., 2016; Styan et al., 2017; Zhigileva \& Gorbacheva, 2017). Similarly, in our study, ISSR markers were functional and convenient for the estimation of genetic diversity and relations in $N$. xanthodon cytotypes $(2 n=$ $54,2 n=60)$.

Acknowledgements. This study was funded by the Scientific Research Project Fund of Bilecik a eyh Edebali University [2015-02.B ${ }^{a} E$ Ü.04-03].

\section{References}

Arslan A. \& Bölükbaş F. 2010. C-heterochromatin and NORs distribution of mole rat, Nannospalax xanthodon from Aksaray, Turkey // Caryologia. Vol.63. P.398-404.

Arslan E., Gülbahçe E., Ar ko lu H., Arslan A., Bužan E.V. \& Kryštufek B. 2010. Mitochondrial divergence between three cytotypes of the Anatolian mole rat, Nannospalax xanthodon // Zoology in the Middle East. Vol.50. P.2734.

Arslan A. \& Zima J. 2014. Karyotypes of the mammals of Turkey and neighbouring regions: a review // Folia Zoologica. Vol.63. P.1-62.

Buczkowska K., Rabska M., Gonera P., Pawlaczyk E.M., Wawrzyniak P., Czołpińska M. \& Bączkiewicz A. 2016. Effectiveness of ISSR markers for determination of the Aneura pinguis cryptic species and Aneura maxima // Biochemical Systematics and Ecology. Vol.68. P.27-35.

Bugarski-Stanojević V., Blagojević J., Adna ević T., Jojić V. \& Vujośević M. 2008. Molecular phylogeny and distribution of three Apodemus species (Muridae, Rodentia) in Serbia // Journal of Zoological Systematics and Evolutionary Research. Vol.46. P.278-286.

Bugarski-Stanojević V., Blagojević J., Stamenković G., Adnađević T., Giagia-Athanasopoulou E.B. \& Vujošević M. 2011. Comparative study of the phylogenetic structure in six Apodemus species (Mammalia, Rodentia) inferred from ISSR-PCR data // Systematics and Biodiversity. Vol.9. P.95-106.

Gromov I.M. \& Baranova G.I. (eds.). 1981. [Catalogue of Mammals of USSR (Pliocene to Recent)]. Leningrad: Nauka. 456 p. [In Russian]

Hadid Y., Nemeth A., Snir S., Pavlicek T., Csorba G., Kazmer M., Major A., Mezhzherin S., Rusin M. \& Coşkun Y. 2012. Is evolution of blind mole rats determined by climate oscillations? // PLoS ONE. Vol.7. P.1-7.

Ivanitskaya E., Sözen M., Rashkovetsky L., Matur F. \& Nevo E. 2008. Discrimination of $2 n=60$ Spalax leucodon cytotypes (Spalacidae, Rodentia) in Turkey by means of classical and molecular cytogenetic techniques // Cytogenetic and Genome Research. Vol.122. P.139-149.

Jojić V., Bugarski-Stanojević V., Blagojević J., \& Vujošević M. 2014. Discrimination of the sibling species Apodemus flavicollis and A. sylvaticus (Rodentia, Muridae) // Journal of Comparative Zoology. Vol.253. P.261-269.

Joshi S.P., Gupta V.S., Aggarwal R.K., Ranjekar P.K. \& Brar D.S. 2000. Genetic diversity and phylogenetic relationship as revealed by inter simple sequence repeat (ISSR) polymorphism in the genus Oryza // Theoretical and Applied Genetics. Vol.100. P.1311-1320. 
Kandemir Ý., Sözen M., Matur F., Kank 1 c T., Martínkova N., Çolak R., Özkurt S.Ö. \& Çolak E. 2012. Phylogeny of species and cytotypes of mole rats (Spalacidae) in Turkey inferred from mitochondrial cytochrome $b$ gene sequences // Folia Zoologica. Vol.61. P.25-33.

Kank 1 ç Te. \& Gürp nar C. 2014. Revised classification design of the Anatolian species of Nannospalax (Rodentia: Spalacidae) using RFLP analysis // Turkish Journal of Zoology. Vol.38. P.68-78.

Kank 1 ç Te., Kank 1 ç To., Sözen M. \& Çolak E. 2013. Genetic diversities and geographic variations of chromosomal forms of Nannospalax nehringi (Satunin, 1898) and Nannospalax ehrenbergi (Nehring, 1898) from Turkey, revealed by RAPD analysis // Acta Zoologica Bulgarica. Vol.65. P.45-58.

Kank 1 ç Te., Kank 1 ç To., Sözen M. \& Colak E. 2015. Allozyme variations in Anatolian populations and cytotypes of the blind mole rats (Nannospalax) // Biochemical Systematics and Ecology. Vol.59. P.126-134.

Kank 1 ç Te., Arslan Atilla, eker P.S., Kank 1 ç To., Toyran K. \& Zima J. 2017. A new chromosomal race $(2 n=44)$ of Nannospalax xanthodon from Turkey (Mammalia: Rodentia) // Zoology in the Middle East. Vol.63. No.3. P.181-188.

Klein Hofmeijer G. \& de Bruijn H. 1985. The mammals from the Lower Miocene of Aliveri (Island of Evia, Greece). IV: The Spalacidae and Anomalomyidae // Proceedings of the Koninklijke Nederlandse Akademie van Wetenschappen. Series B. Palaeontology, Geology, Physics, Chemistry, Anthropology. Vol.88. No.2. P.185-198.

Kryštufek B. \& Vohralik V. 2009. Cricetinae, Muridae, Spalacidae, Calomyscidae, Capromyidae, Hystricidae, Castoridae // Mammals of Turkey and Cyprus. Rodentia II. Koper, Slovenia: Knji॰nica Annales Majora. P.242-280.

Kryštufek B., Ivanitskaya E., Arslan A., Arslan E. \& Buzan E. 2012. Evolutionary history of mole rats (genus Nannospalax) inferred from mitochondrial cytochrome $b$ sequence // Biological Journal of the Linnean Society. Vol.105. No.2. P.446-455.

Matur F., Çolak F., Sevindik M. \& Sözen M. 2011. Chromosome differentiation of four $2 n=50$ chromosomal forms of Turkish mole rat, Nannospalax nehringi // Zoological Science. Vol.28. P.61-67.

Nei M. 1978. Estimation of average heterozygosity and genetic distance from a small number of individuals // Genetics. Vol.89. P.583-590.

Nevo E. 1991. Evolutionary theory and processes of active speciation and adaptive radiation in subterranean mole rats, Spalax ehrenbergi superspecies, in Israel // Evolutionary Biology. Vol.2. P.1-125.

Nevo E., Filippucci M.G., Redi C., Korol A. \& Beiles A. 1994. Chromosomal speciation and adaptive radiation of mole rats in Asia Minor correlated with increased ecological stress // Proceedings of the National Academy of Sciences of the USA. Vol.91. P.8160-8164.

Nevo E., Filippucci M.G., Redi C., Simson S., Heth G. \& Beiles A. 1995. Karyotype and genetic evolution in speciation of subterranean mole rats of the genus Spalax in Turkey // Biological Journal of the Linnean Society. Vol.54. P.203-229.

Savic I. \& Nevo E. 1990. The Spalacidae: Evolutionary history, speciation, and population biology // Nevo E. \& Reig O.A. (eds.). Evolution of Subterranean Mammals at the Organismal and Molecular Levels. New York: Alan R. Liss, Inc. P.129-143.
Sözen M., Cataklý K., Ero lu F., Matur F. \& Sevindik M. 2011. Distribution of chromosomal forms of Nannospalax nehringi (Satunin, 1898) (Rodentia: Spalacidae) in Çankýrý and Çorum provinces, Turkey // Turkish Journal of Zoology. Vol.35. No.3. P.367-374.

Sözen M., Çolak F., Sevindik M. \& Matur F. 2013. Cytotypes of Nannospalax xanthodon (Satunin, 1898) (Rodentia: Spalacidae) from western Anatolia // Turkish Journal of Zoology. Vol.37. P.462-469.

Sözen M., Çolak F., Sevindik M. \& Matur F. 2015. Two new cytotypes and some additional karyologýcal records for Anatolian mole rats of the Nannospalax xanthodon and Nannospalax ehrenbergi (Mammalia, Rodentýa) in Turkey // Folia Zoologica. Vol.64. No.2. P.167-172.

Styan C.A., McCluskey C.F., Sun Y. \& Kupriyanova E.K. 2017. Cryptic sympatric species across the Australian range of the global estuarine invader Ficopomatus enigmaticus (Fauvel, 1923) (Serpulidae, Annelida) // Aquatic Invasions. Vol.12. No.1. P.53-65.

Suzuki H., Wakana S., Yonekawa H., Moriwaki K., Sakurai S. \& Nevo E. 1996. Variations in ribosomal DNA and mitochondrial DNA among chromosomal species of subterranean mole rats // Molecular Biology and Evolution. Vol.13. P.85-92.

Topachevskii V.A. 1969. [Mole rats Spalacidae] // Fauna SSSR. Mlekopitayushchie. Vol.3. No.3. Leningrad: Nauka. 308 p. [In Russian]

Wahrman J., Goitein R. \& Nevo E. 1969. Geographic variation of chromosome forms in Spalax, a subterranean rodent of restricted mobility // Benirschke K. (ed.). Comparative Mammalian Cytogenetics. Berlin, Heidelberg: Springer. P.30-48.

Ya c T. 2010. [G-banding and allozyme variations of Nannospalax leucodon (Nordmann, 1840) in Central Anatolia Region (Mammalia: Rodentia)] // PhD Thesis. Kýrýkkale University. Kýrýkkale. 103 p. [in Turkish].

Yeh F.C., Yang R.C. \& Boyle T. 1999. Popgene Version 1.31 Microsoft Windows-based Software for Population Genetics Analysis. Alberta, Canada: University of Alberta and Centre for International Forestry Research. 28 p.

Yi it N., Çolak E. \& Sözen M. 1999. Habitats of Turkish rodents (Mammalia: Rodentia) and their effects of cultivated fields // Journal of the Institute of Science Technology, Gazi Üni. Vol.12. No.4. P.885-903.

Yi it N., Çolak E., Sözen M. \& Karata A. 2006. Rodents of Türkiye. Ankara: Meteksan Co. 154 p.

Yüksel E. \& Gülkaç M.D. 1990. The evolution and phylogenetic relationship in some subspecies and chromosomal forms of Spalax leucodon // Turkish Journal of Biology. Vol.14. P.59-68.

Zhigileva O.N. \& Gorbacheva E.V. 2017. Distribution and parameters of genetic polymorphism in northern redbacked vole (Clethrionomys rutilus) and bank vole (Clethrionomys glareolus) in West Siberia // Contemporary Problems of Ecology. Vol.10. P.1-8.

Zhigileva O.N., Politov D.V., Golovacheva I.M. \& Petrovicheva S.V. 2014. Genetic variability of sable Martes zibellina $\mathrm{L}$., pine marten $M$. martes $\mathrm{L}$. and their hybrids in West Siberia: polymorphism of proteins and DNA // Russian Journal of Genetics. Vol.50. P.508-517.

Zietkiewicz E., Rafalski A. \& Labuda D. 1994. Genome fingerprinting by simple sequence repeats (SSR)-anchored PCR amplification // Genomics. Vol.20. P.176-183. 